Revista Perspectivas Online: Exatas \& Engenharias Anais do V Seminário P\&D PROVIC/PIBIC

II Encontro de Iniciação Científica CNPq

Vol. 10, n² 29, Suplemento, 2020

\title{
Mapeamento das Áreas de Preservação Permanente do rio Paraíba do Sul a montante do distrito sede do município de Campos dos Goytacazes - RJ
}

\author{
Jhonny Lacerda ${ }^{1}$, Camille Pereira de Oliveira ${ }^{2}$, Ronaldo de Sousa Araújo ${ }^{3}$, Zélia Maria \\ Peixoto Chrispim ${ }^{4}$ \\ (1) Aluno de Iniciação Científica do PIBIC/CNPq - Curso Engenharia Civil; (2) Aluna de Iniciação Científica do PIBIC/ISECENSA - Curso \\ Engenharia Civil; (3) Pesquisador Colaborador - Laboratório de Estudos Urbanos e Ambientais - LEUA - Curso de Arquitetura e Urbanismo; (4) \\ Pesquisador Orientador - Laboratório de Pesquisa em Gestão e Tecnologias na Construção Civil - GETECC - Curso de Engenharia Civil - Institutos \\ Superiores de Ensino do CENSA - ISECENSA, Rua Salvador Correa, 139, Centro, Campos dos Goytacazes, RJ, Brasil
}

O trabalho realizado teve como seu escopo principal o estudo das áreas de mata ciliar nativa as margens rio Paraíba do Sul em sua região montante ao centro urbano do município de Campos dos Goytacazes. Baseando sua elaboração seguindo as diretrizes do Novo Código Florestal (Lei $n^{\circ} 12.651 / 2012$ ) para o levantamento e demarcação das margens do corpo hídrico e suas respectivas áreas que ainda permanecem cobertas com vegetação, convencionadas como Áreas de Preservação Permanente (APPs). O projeto teve como o objetivo quantificar estas áreas florestadas as margens do rio por todo o percurso a partir da divisa municipal entre São Fidélis e Campos dos Goytacazes, esboçando o cenário em que se encontra atualmente a situação das APPs. A metodologia aplicada na execução deste trabalho foi: estudos bibliográficos com leitura de artigos, leis, teses, dissertações, mapas, cartilhas de órgãos ambientais, imagens de satélites; elaboração de mapas, gráficos e tabelas. O desenvolvimento deste trabalho visa trazer para a população e órgãos gestores subsídios para a tomada de decisão em relação aos recursos hídricos e suas condições de preservação. Assim, contribuindo para o planejamento de ações que possa garantir a qualidade da água que chega aos munícipes de Campos. Durante a execução da pesquisa foi possível observar que os parâmetros mínimos de APP estipulados pela lei, raramente foram encontrados no percurso estudado, havendo uma grande defasagem dos valores ideias para considerar as margens devidamente protegidas. Os resultados encontrados a montante podem ser considerados alarmantes, com 92,25\% de área sem cobertura de vegetação nativa. Ações por parte do poder público devem ser estudadas, buscando meios para que haja uma adequação destas áreas sem cobertura de vegetação junto às atividades que utilizam as margens do rio para fins econômicos, preservando o interesse mútuo pela exploração sustentável das margens do rio Paraíba do Sul e os valores estipulados por lei.

Palavras-chave: Recursos hídricos. Mata ciliar. Código Florestal. APP.

Instituição de Fomento: ISECENSA; CNPq. 